\title{
A new species of the genus Gyranusoidea Compere, 1947 (Hymenoptera, Encyrtidae) from Cuba
}

\author{
Новый виА рода Gyranusoidea Compere, 1947 \\ (Hymenoptera: Encyrtidae) с Кубы
}

\author{
V.A. Trjapitzin \\ B.A. Тряпицын
}

Do vostrebovania, Post Office 129344 (7 ulitsa Letchika Babushkina), Moscow, Russia. До востребования, п/о 129344 (ул. Летчика Бабушкина, д. 7), Москва, Россия.

KEY WORDS: Hymenoptera, Encyrtidae, Gyranusoidea, taxonomy, Gyranusoidea baranowskayae sp.n., Cuba, Homoptera, Pseudococcidae, Maconellicoccus hirsutus, Rastrococcus invadens, biocontrol.

КЛЮЧЕВЫЕ СЛОВА: Нуmеnoptera, Encyrtidae, Gyranusoidea, таксономия, Gyranusoidea baranowskayae sp.n., Куба, Homoptera, Pseudococcidae, Maconellicoccus hirsutus, Rastrococcus invadens, биометод.

ABSTRACT. Diagnosis of the genus Gyranusoidea Compere, 1947 (Hymenoptera: Encyrtidae) and description of $G$. baranowskayae sp.n. from Cuba are given. G. baranowskayae sp.n. is designated as the type species of the subgenus Dzera Trjapitzin, subgen.n. Species of Gyranusoidea with known hosts are parasitoids of mealybugs (Homoptera: Pseudococcidae). Special attention is paid to $G$. indica Shafee, Alam et Agarwal, 1975 and G. tebygi Noyes, 1988 successfully employed in programs of classical biological control.

How to cite this article: Trjapitzin V.A. 2018. A new species of the genus Gyranusoidea Compere, 1947 (Hymenoptera, Encyrtidae) from Cuba// Russian Entomol. J. Vol.27. No.1. P.47-50. doi: 10.15298/ rusentj.27.1.07

РЕЗЮМЕ. В статье приводятся диагноз рода Gyranusoidea Compere, 1947 (Hymenoptera: Encyrtidae) и описание G. baranowskayae sp.n. с Кубы. G. baranowskayae sp.n. обозначен как типовой вид подрода Dzera subgen.n. Виды Gyranusoidea с известными хозяевами являются паразитоидами мучнистых червецов (Homoptera: Pseudococcidae). Особое внимание уделено G. indica Shafee, Alam et Agarwal, 1975 и G. tebygi Noyes, 1988, с успехом применявшимся в программах классического биологического метода.

\section{Introduction}

The genus Gyranusoidea Compere, 1947 belongs, according to Trjapitzin [1989] to the subfamily Tetracneminae Howard, 1982, the tribe Anagyrini Hoffer, 1953, the subtribe Anagyrina Hoffer, 1953. Its species inhabit predominantely tropical and subtropical regions of the world. They infest mealybugs (Homoptera: Pseudococcidae) on many plants, including such impor- tant cultures as lemon tree Citrus limon, coffee tree (Coffea), cacao tree Theobroma cacao, mango Mangifera indica, grapes Vitis vinifera, pomegranate Punica granatum, coconut palm Cocos nucifera, cassava Manihot esculenta, and okra Abelmoschus esculentus. Among these mealybugs there are very dangerous pests, for example Maconellicoccus hirsutus (Green), infesting more than 200 species of plants. In the case of accidental penetration of this and other pseudococcids into subtropics of Crimea, Black Sea Coast of Caucasus and Lenkoran", or to greenhouses, it would be necessary introduction of their natural enemies, including species of the genus Gyranusoidea.

During preparation of this contribution I examined materials on Gyranusoidea in depositories of SanctPetersburg, London, Madrid, Riverside (California, USA) and Cd. Victoria (Mexico).

An abbreviation used in the text is: F - funicular segment of antenna.

\section{Genus Gyranusoidea Compere, 1947}

Gyranusoidea Compere, 1947: 17. Type species: Gyranusa citrina Compere, 1938, by original designation.

Leptanusia De Santis, 1964: 44, 80-81. Type species: Leptomastidea pseudococci Brèthes, 1924, by original designation. Synonymy with Gyranusoidea by Noyes, Hayat, 1994: 308 - 309.

Neuranagyrus Bouček, 1977 (February): 140-141. Type species: Heterarthrellus aphycoides Mercet, by original designation. Synonymy with Gyranusoidea by Kerrich, 1982: 401 and Prinsloo, 1983: 103.

Therencyrtus Trjapitzin, 1977 (June): 159-160. Type species: Heterarthrellus aphycoides Mercet, 1921, by original designation. Synonymy with Neuranagyrus by Kerrich, 1982: 401 and with Gyranusoidea by Trjapitzin, 1989: 128.

Mercet, 1921: 239-241 (Heterarthrellus sensu Mercet, only female); Compere, 1947: 17; De Santis, 1964: 80-83 (Leptanusia); Annecke, Mynhardt, 1970: 35-42; Bouèek, 1977: 140-141 (Neuranagyrus); Trjapitzin, 1977: 159-160 (Therencyrtus); Prinsloo, 1983: 103-113; Noyes, Hayat, 1984: 230, 280-281; Noyes, 1988: 79-80; Trjapitzin, 1989: 74, 102, 128; Noyes, Hayat, 1994: 36, 308-332; Noyes et al., 1997: 190, 201, 203, 209, 214, 262; 
Noyes, 2000: 15, 16, 138-162; Trjapitzin et al., 2004: 77-80; Hayat, 2006: 46, 47, 253-255; Trjapitzin et al., 2008: 33, 60, 81, $157-158$.

DIAGNOSIS. Female. Body moderately robust. Head hypognathous. Occipital margin sharp. Frontovertex less than 0.5 head width, its sculpture regular, hexagonally reticulate. Antennal scape somewhat broadened and flattened, or sublinear; funicle 6-segmented, with all segments longer than wide; clava 3-segmented, its septa transverse. Mandible with 2 teeth at apex. Mesoscutellum without parapsidal lines. Wings not abbreviated: postmarginal vein of the fore wing at least slightly longer than stigmal vein. Gaster not longer than thorax. Ovipositor sheaths never strongly exserted. Body length $0.64-3.0 \mathrm{~mm}$.

Male. All funicular segments of antenna with long hairs; clava solid.

DISTRIBUTION. Most of 42 described species of the genus Gyranusoidea were recorded from Neotropical (15), Indo-Malayan (12) and Afrotropical (11) regions. Certainly, not all the species are endemic in these regions, because of their penetration there with hosts or being purposely introduced. In Palearctic only the following 4 species were discovered: G. advena Beardsley, 1969 (Greece); G. aphycoides (Mercet, 1921) (Spain, England, Greece); G. indica Shafee, Alam et Agarwal, 1975 (Egypt, Japan); G. litura Prinsloo, 1983 (Egypt). Among them only $G$. aphycoides is a conditional endemic. $G$. advena in Greece and $G$. indica in Egypt are accidental immigrants, but concerning $G$. indica in Iran and $G$. litura in Egypt the question is unsolved.

Gyranusoidea iranica Japoshvili et Fallahzadeh, 2010 does not belong to the genus Gyranusoidea because it has very short postmarginal vein of the fore wing. This species has been described from Fars Province of Iran as a parasitoid of Chorizococcus sp. on grapes (In: Fallahzadeh, Japoshvili, 2010). It is impossible to determine this genus without examination of the specimens.

The genus Gyranusoidea was still not indicated to Cuba.

BIOLOGICAL CONTROL. Two species of Gyranusoidea were successfully used in programs of classical biological control:

I. Gyranusoidea indica Shafee, Alam et Agarwal, 1975. This species had been described primarily from India as a parasitoid of Nipaecoccus viridis Newstead, however its main host in pink hibiscus mealybug Maconellicoccus hirsutus (Green). According to Daane et al. [2008], the region of origin of this mealybug is South-East Asia or Australia. It invaded Egypt (1912), Hawaiian Islands (1984), Caribbean Islands (1994), Florida, and in 2003 attained northern Mexico and southern California (in USA). In California it insfests culture of grapes Vitis vinifera. As a pest, M. hirsutus is very dangerous.

After detection of Maconellicoccus hirsutus in the Caribbean zone, entomologists of USA began to search its natural enemies in some countries of the Old World. They paid attention to Egypt, in collaboration with Egyptian specialists. Awadallah et al. [1999] reared there some parasitoids of $M$. hirsutus, and among them - Anagyrus kamali Moursi, 1948 and $G$. indica on Hibiscus rosa-sinensis, and these data were confirmed by Mousa et al. [2001] and González et al. (2003). I do not have information about intended introduction of $G$. indica into Egypt, but it is probable that this species has been shipped there accidentally together with A. kamali during introduction of parasitoids of $M$. hirsutus from Indonesia in 1930 s.

Gyranusoidea indica, together with Anagyrus kamali, was introduced from Egypt into Western Hemisphere, namely on
Caribben islands St. Thomas and St. Kitts, and soon was found in Trinidad. It was liberated also in Puerto Rico, on U.S. Virgin Islands, on the island Grenada, and probably on some islands subjected to Netherlands. This program of biological control was carried out by support of "APHIS" (U.S. Department of Agriculture - Animal and Plant Inspection Service). In 1997, "APHIS", together with Department of Agriculture of U.S. Virgin Islands, founded on the island St. Thomas a laboratory for mass production of $A$. kamali and $G$. indica which were sent to some other islands of the West Indies. In November of 2000, M. hirsutus was discovered on the island New Providence (Bahamas), and in January 2001 A. kamali and G. indica were introduced there from Puerto Rico. To April 2001, population of the pest on New Providence island was strongly reduced. On the American Continent (in Central America) $G$. indica was successfully introduced into Belize, where established. Introduction and acclimatization of these two parasitoids in the Caribbean region led to effective biological suppression of $M$. hirsutus [Goolsby et al., 2002].

In USA $M$. hirsutus was discovered in the Imperial Valley of Southern California near Mexican border, where it strongly infested grapes. Already in a month after, A. kamali and $G$. indica were introduced there. However, it was unknown, how they would tolerate hot and dry conditions of this valley, inspite of first results occurred to be positive [Goolsby et al., 2002]. So, explorations were carried out in climatically similar parts of Australia, where M. hirsutus was perfectly controlled by predators and parasitoids and only rarely became injurious. $G$. indica was collected in Australia in Annona squamosa, citrus cultures, soya Glycine max, cotton (Gossypium) and Hibiscus sp. Molecular studies before introduction of $G$. indica from Australian state Queensland into California confirmed identity of the Australian population acclimatized in California (sequences $\mathrm{D}_{2}$ ). Roltsch et al. [2006] and Daane et al. [2008] informed about suppression of $M$. hirsutus by $A$. kamali and $G$. indica in California. Brilliant realization of this scientific and practical program testifies about unfading importance of classical biological control of pests.

II. Gyranusoidea tebygi Noyes, 1988. This very effective parasitoid of the mealybug Rastrococcus invadens Williams, living on mango Mangifera indica, was described primarily from India and discovered also in Malaysia (Malaya) and Indonesia (Sulawesi). According to Vavilov [1966], the native area of mango is the Indian centre of origin of cultivated plants (see also: Klingen, 1960). In the beginning of 1980s, $R$. invadens penetrated into tropical West Africa, where caused great damage to cultures of mango, citrus and other plants. In 1987, G. tebygi was sent from India to England and studied there in laboratory conditions and in the same year introduced into Togo where the parasitoid promptly established, and already within 18 months an essential biological control of the pest was attained. After that G. tebygi was imported into Benin, Ghana, Gabon, Kongo, Nigeria and Zaire, together with Anagyrus mangicola Noyes, 1990. The result of these introductions was effective suppression of $R$. invadens (Noyes, Hayat, 1994).

\section{Gyranusoidea baranowskayae Trjapitzin sp.n.} Fig. 1.

TYPE MATERIAL. Holotype: + , Cuba, Prov. Matanzas, Varadero, 15.XI.1986 (Emeljanov). In the collection of Zoological Institute, Russian Academy of Sciences in St. Petersburg. The holotype specimen is point-mounted; funicle and clava of the right antenna are detached and glued on the same triangle to the left of the specimen. 


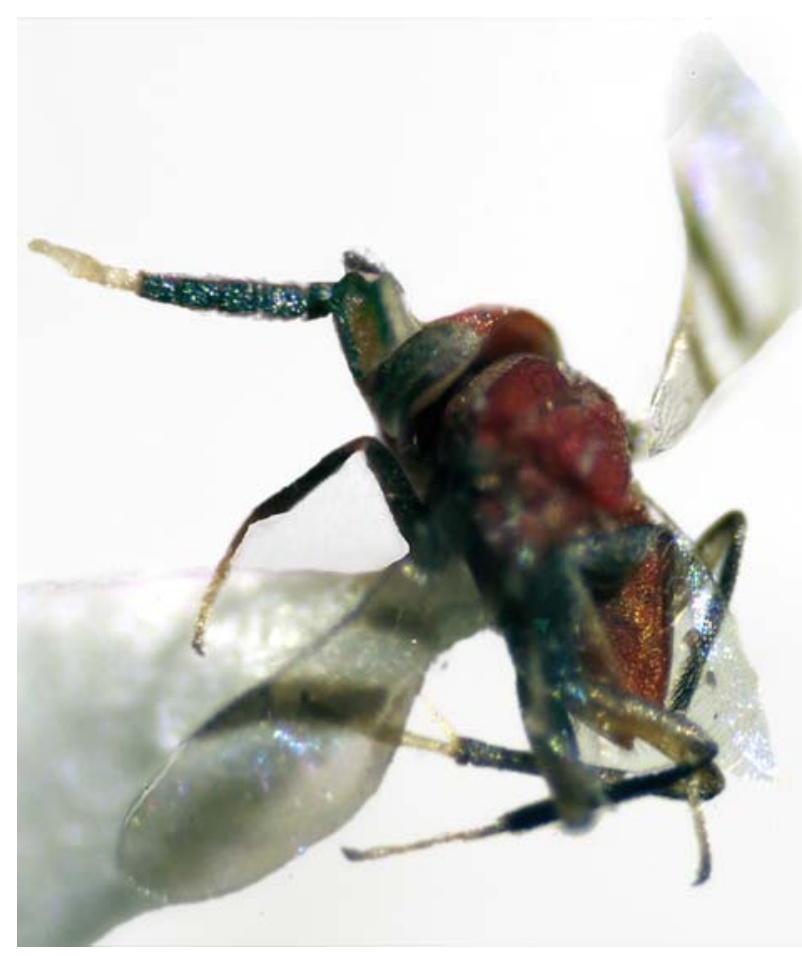

Fig. 1. Gyranusoidea baranowskayae sp.n., female antenna (photo by A.K. Akhatov).

Рис. 1. Gyranusoidea baranowskayae sp.n., усик самки (фото А.К. Ахатова).

Female. Occipital margin slightly concave, posterior margins of eyes almost touching it. Frontovertex about $1 / 2$ head width and as long as wide. Ocelli small; apical angle of ocellar triangle somewhat more than $90^{\circ}$; distance between posterior ocelli more than distance from them to the anterior ocellus; posterior ocelli not far from margin of occiput. Anterior margin of frons (seen from above) somewhat convex, in this position the interantennal prominence is visible. Scrobes straight, converging above under an acute angle, but not meeting. Toruli at the level of lower eye margins. Scape of antenna $2 \mathrm{x}$ as long as wide, its dorsal edge horizontally flattened, broandening to apex of the segment, this flattened part is separated from its inner surface by an acute ridge; pedicel $3 \mathrm{x}$ shorter than scape and $2 \mathrm{x}$ as long as wide at apex, its dorsal side being horizontally flattened as on scape; F1 1.5-2x as long as wide; F2 as long as F1 or shorter (3: 4) and hardly longer than wide; F3 as long as or a little shorter than F2 and somewhat longer than wide (5: 4); F5 narrower than F4 and with similar proportions; F6 slightly longer than wide or subquadrate; clava $2 \mathrm{x}$ as long as wide and as long as 2 preceding funicular segments combined. Malar space less than eye height (16:23). Mouth margin convex. Oral orifice very narrow. Pronotum short, transverse, dorsally $7 \mathrm{x}$ as wide as long. Mesoscutum 2x as wide as long. Scutellum longer than mesoscutum (3:2), as long as wide, triangular, its lateral margins almost straight, and apex roundly pointed. Wings not abbreviated; the fore wing $3.3 \mathrm{x}$ as long as wide; costal cell only hardly visible near the base of the wing; submarginal vein thin; marginal vein may be characterized as punctiform; stigmal vein straight, somewhat thickened, with uncus at apex; postmarginal vein very long, at least $3 \mathrm{x}$ as long as stigmal. Mesotibial spur as long as the $1^{\text {st }}$ segment of mid tarsus. Propodeum very short in the middle, where is $6 \mathrm{x}$ shorter than scutellum, but only a little shorter than it at sides. Gaster somewhat shorter than mesosoma, triangular (seen from above); dorsal part of the first gastral (III abdominal) tergite with convexely rounded posterior margin. Ovipositor sheaths not exserted.

Frontovertex orange. Face reddish orange, slightly infuscate under the level of lower eye margins. Radicula of antenna black; scape orange-brown on outer side, with black dorsal and ventral margins, its apical part dark with strong bronzegreen lustre; colour of inner side of scape is similar, but without infuscation in its apical part; dorsal, horizontally flattened, part of scape with a longitudinal whitish stripe and with dark apex; pedicel black, dorsally whitish; F1-F5 black, F6 and clava yellowish white. Dorsal side of pronotum yellow-orange. Mesoscutum, axillae and scutellum red; tegulae black. Mesopleura blackish red; metapleura black. The fore wing with 2 obliquely transverse fuscous stripes: the first at a distance about $1 / 4$ of the wing length; the second about $2 x$ wider, somewhat not reaching posterior margin of wing at a distance of $5 / 95$ of the wing length; apical part of wing slightly infuscate. Legs black, with hind femora brownish; mesotibial spur and all tarsi (except their last segment) whitish yellow. Propodeum blackish red. Gaster black with IX syntergite orange-red and lateral parts of the first gastral (III abdominal tergite) blackish red.

Male unknown.

BIOLOGY unknown.

ETYMOLOGY. The species is named after Irina Anatolievna Baranowskaya, phytogelmintologist; she worked on Cuba.

REMARKS. This species differs from all described species of the genus Gyranusoidea in having dorsal edges of antennal scape and pedicel horizontally flattened. This permits me to establish here for it a Dzera Trjapitzin, subgen.n. with the type species Gyranusoidea baranowskayae sp.n.

ACKNOWLEDGEMENTS. I am thankful to my son Dr. Serguei Vladimirovich Triapitsyn (University of California, Riverside, CA, USA) for sending some literature necessary for this article.

\section{References}

Annecke D.P., Mynhardt M.J. 1970. New species of Gyranusoidea Compere, 1947 and Clausenia Ishii from South Africa (Hymenoptera: Encyrtidae) // Journal of the Entomological Society of South Africa. Vol.33. No.1. P.35-47.

Awadallah K.T.A., Ibrahim A.-A.M.A., Atia A.R., Nada M.A. 1999 (1997). Survey of mealybug parasitoids and their associated hyperparasitoids on certain ornamental host plants at Giza Region // Bulletin of the Entomological Society of Egypt. Vol.77. P. 97-101.

Bouček Z. 1977. On Hofferencyrtus (gen. nov.), Mira, Lyka and some other European Encyrtidae (Hymenoptera)// Journal of Natural History. Vol.11. No.2. P.137-154.

Compere H. 1947. A report on a collection of Encyrtidae with description of new genera and species // University of California Publications in Entomology. Vol.8. No.1. P. 1-24.

Daane K.M., Cooper M.L., Triapitsyn S.V., Walton V.M., Yokota G.Y., Haviland D.R., Bentley W.J., Godfrey K.E., Wanderlich L.R. 2008. Vineyard managers and researchers seek sustainable solution for mealybugs, a changing pest complex // California Agriculture. Vol.62. No.4. P. 167-171, 173, 175-176.

De Santis L. 1964 (1963). Encírtidos de la República Argentina (Hymenoptera: Chalcidoidea) // Anales de la Comisión de Investigación Científica de la Gobernación de la Provincia de Buenos Aries. Vol.4. P.9-422. 
Fallahzadeh M., Japoshvili G. 2010. Checklist of Iranian encyrtids (Hymenoptera: Chalcidoidea) with descriptions of new species // Journal of Insect Science. Vol.10. Art.68. P.1-24.

González D., El-Heneidy A.H., Mousa S.M., Triapitsyn S.V., Adley D., Trjapitzin V.A., Meyerdirk D.E. 2003. A survey for pink hibiscus mealybug Maconellicoccus hirsutus (Green) and its parasitoids in Egypt, Spain and Morocco // Egyptian Journal of Biological Pest Control. Vol.13. No.1. P.1-5.

Goolsby J.A., Kirk A.A., Meyerdirk D.E. 2002. Seasonal phenology and natural enemies of Maconellicoccus hirsutus (Hemiptera: Pseudococcidae) in Australia // Florida Entomologist. Vol.85. No.3. P.494-498.

Hayat M. 2006. Indian Encyrtidae (Hymenoptera: Chalcidoidea) // Aligarh Muslim University, published by M. Hayat. VIII + 496 p.

Kerrich G.J. 1982. Further systematic studies on tetracnemine Encyrtidae (Hym., Chalcidoidea) including a revision of the genus Apoanagyrus Compere // Journal of Natural History. Vol.16. No.3. P.399-430.

Klingen I.N. 1960. [Among patriarchs of agriculture of the peoples of Near and Far East. Egypt, India, Ceylon, China]. Moscow: Edition of Agricultural Literature. 604 p. [In Russian]

Mercet R.G. 1921. Himenópteros fam. encírtidos. Fauna Ibérica. Madrid. XI + $732 \mathrm{p}$

Mousa S.F., El-Heneidy A.H., Hendawy A.S., Adly D., González D. Triapitsyn S.V. 2001. Pink hibiscus mealybug, Maconellicoccus hirsutus (Green), parasitoids in Egypt. 1 - preliminary record // Egyptian Journal of Biological Control. Vol.11. No.2. P.195-196.

Noyes J.S. 1988. Gyranusoidea tebygi sp.n. (Hymenoptera: Encyrtidae), a parasitoid of Rastrococcus (Hemiptera: Pseudococcidae) on mango in India // Bulletin of Entomological Research. Vol.78. P.313-316.

Noyes J.S. 2000. Encyrtidae of Costa Rica (Hymenoptera: Chalcidoidea), 1. The subfamily Tetracneminae, parasitoids of mealybugs (Homoptera: Pseudoccidae) // Memoris of the American Entomological Institute. Vol.62. P.1-355.

Noyes J.S., Hayat M. 1984. A review of the genera of Indo-Pacific Encyrtidae (Hymenoptera: Chalcidoidea) // Bulletin of the British Museum (Natural History). Entomology series. Vol.48.
No.3. P.131-395.

Noyes J.S., Hayat M. 1994. Oriental mealybug parasitoids of the Anagyrini (Hymenoptera: Encyrtidae) with a world review of Encyrtidae used in classical biological control and an index of encyrtid parasitoids of mealybugs (Homoptera: Pseudococcidae). Wallingford, Oxon, U.K.: CAB International. VIII + 554 p.

Noyes J.S., Woolley J.B., Zolnerowich G. 1997. Chapter 8. Encyrtidae // Gibson G.A.P., Huber J.T., Woolley J.B. (eds.). Annotated keys to the genera of Nearctic Chalcidoidea (Hymenoptera). Ottawa: NRC Research Press. P.170-320.

Prinsloo G.L. 1983. The southern African species of the genus Gyranusoidea Compere (Hymenoptera: Encyrtidae) // Journal of the Entomological Society of South Africa. Vol.46. No.1. P.103-113.

Roltsch B.J., Meyerdirk D.E., Warkentin R., Andress E.R., Carrera K. 2006. Classical biological control of the pink hibiscus mealybug Maconellicoccus hirsutus (Green), in southern California // Biological Control. No.37. P.155-166.

Trjapitzin V.A. 1977. New genera and species of parasitic Hymenoptera of the family Encyrtidae (Hymenoptera: Chalcidoidea) // Folia Entomologica Hungarica (Ser. Nova). Vol.30. No.1. P.153-166.

Trjapitzin V.A. 1989. [Parasitic Hymenoptera of the fam. Encyrtidae of Palearctic]. Leningrad: Nauka Publishing. 489 p. [In Russian]

Trjapitzin V.A., Bennett F.D., Ruíz-Cancino E., Coronado-Blanco J.M. 2004. Annotated check list of encyrtids (Hymenoptera: Chalcidoidea: Encyrtidae) of Central America, the West Indies and Bermuda. Universidad Autónoma de Tamaulipas (Cd. Victoria, Tamaulipas, México). 205 p.

Trjapitzin V.A., Myartseva S.N., Ruíz-Cancino E., Coronado-Blanco J.M. 2008. Clave de géneros de Encyrtidae (Hymenoptera: Chalcidoidea) de México y un catálogo de las especies // Serie Avispas Parasíticas de Plagas y otros Insectos, Universidad Autónoma de Tamaulipas (Cd. Victoria, Tamaulipas, México). Editorial Planea. Num.4. P.1-266.

Vavilov N.I. 1966. [Botanic-geographical bases of selection. (Doctrine of initial material for selection)] // Selected works. Genetic and selection. Moscow: Kolos Publ. P.176-225 [in Russian]. 